\title{
Boy-Child Participation and Retention in Public Secondary Schools: The Role of Socio-Economic Factors with Examples from Baringo County, Kenya
}

\author{
Emily J. Amdany \\ Moi University, P. O. Box 3900-30100, Kenya;
}

\begin{abstract}
This paper is premised on the findings of a study that sought to investigate factors that influence the participation and retention of the boy-child in public secondary schools in Baringo County, Kenya. Specifically, the study aimed at evaluating the effects of socio-economic factors on boy-child participation and retention in public secondary schools in Baringo County. Principles of the education production function theory guided the study. The study adopted a pragmatic world view (mixed method approach) with a sample size of 573 comprising form three boys' students, teachers and Quality Assurance and Standards Officers from Baringo County. The researcher adopted stratification, simple random sampling and purposive strategies for setting up samples. Questionnaires, interview schedules and document analysis were used for data collection and data analyzed using SPSS (ver 20). The study established that there are socio-economic and school-related factors affecting participation and retention of boys. In particular, poverty, family size and number of siblings per household, child labour and desire for earnings, and educational attainment of parents determine boy participation and retention in public secondary schools in Baringo County. The paper concludes that financial constraints hinder the participation and retention of boys in public secondary schools in Baringo County due to the fact that the meagre resources that are available are channelled to catering for basic survival. The paper recommends that measures should be put in place to ensure that needy students receive financial aid towards achieving their educational goals.
\end{abstract}

Key Words: Boy-Child, Retention, Participation, Secondary School, Socio-Economic, Baringo County

\section{Introduction \\ 1.1 The Role of Education vs the Increasing Boy Drop Out Rates}

Access to basic education lies at the heart of development. Lack of educational access, and securely acquired knowledge and skills, are both part of the definition of poverty, and a means for its diminution. Sustained access to meaningful learning that has value is critical to long term improvements in productivity, the reduction of inter-generational cycles of poverty, demographic transition, preventive health care, the empowerment of youths, and reductions in inequality in education. Quality education is influenced by several factors which include access to education, retention rates, transition rates, dropout rates and adequacy of instructional resources [1]. Participation rates for secondary education in Sub-Saharan Africa (SSA) are lower than any region of the world, with access biased in favour of the wealthier populations [1,2]. Lack of access to secondary education is increasingly seen to constrain abilities of some countries to pursue effective economic growth and development strategies. This makes governments and the funding community to place increased emphasis on the expansion of secondary education $[1,2]$.

Education is regarded as a prime mover for socio-economic development and self development [3]. Education improves productivity, thus reducing poverty by imparting knowledge, skills, attitudes, behaviour traits, often known as socio-cultural capital [4]. Education is seen as a tool for alleviating poverty, harmonious co-existence, and thus a fundamental human right [5]. For this reason, nations are concerned over provision of education to its citizens all over the world [6]. Globally, more emphasis has been on increasing the girl child education by enhancing access and retention at the expense of boy child [1]. After Kenya's independence, education goals were aimed at fighting against poverty and illiteracy.

According to Todaro [7], the cause of drop out varies from region to region, country to country, and school to school. The rate of drop out stood at $2.1 \%$ for boys and $2.0 \%$ for girls [8]. A study carried out by Kimondo [9] indicated that boy drop out was now higher than that of girls, especially in the Arid and Semi-Arid Land (ASAL) areas. Given this escalating rates, there is a need to establish the underlying factors for this drop out of boys from high schools and to establish why boy child participation and retention is still very low. Gatere [10] and Kimondo [9] aver that the boy's education has been endangered because of dropout rates. Further, Njeru and Orodho [11] have observed that there has been a considerable decline in gross enrolment rates by gender and severe disparities in access are evident in ASAL areas. Government policies are geared towards support of education bringing in political, social, economic and cultural advancement [12]. 
Studies carried out in Ghana, on access and retention, have revealed that although their government is committed to give education, children from poor households continue to stay out of school [13, 14]. In addition, studies carried out in Malawi on education access have revealed that children from poor households cannot enrol and complete education [15]. In Baringo County, socio-economic challenges such as lack of basic needs inhibit the boy child from achieving secondary education. The politics in the region and insecurity issues have all contributed to the dropout of boys from schools. The remoteness of some parts of Baringo County has been a challenge too because a large number of teachers are unwilling to teach in such areas, especially, if they are not from the region [16]. The transition rates from secondary to higher levels of education for boys are still very low at $8 \%$.

Researchers have postulated that poverty is the main reason to low participation in schooling $[17,18)$. Wanjiru [19] assessed factors of low retention of boys in Mombasa and attributed it to socio-economic factors. From the findings of a study carried out in Bungoma, Hamasi [20] postulates that some boys dropped to engage in economic activities such as 'Boda Boda' business. Nyongesa [21] asserts that the trend of boys dropping out is threatening and has adverse effects on education and the future generations due to high wastage rates. Wastage through drop out undermines education goals set right from independence to Vision 2030 targets and MDG's targets [22]. Changach [23] attributes low participation rates of boys to socio-economic factors that prevent poor students from transiting to next levels of education. An online article entitled 'The African boy' an endangered species' argues that whereas society is fast to rescue the girl child, it is now slow to act on the boy child. If this trend continues, it will pose a serious threat to gains in education in Baringo County, as well as the participation of the boy-child in national building.

Data from Baringo County Director of Education, as shown in Table 1, indicates that the enrolment of boys in KCSE examination has been less than those of girls in the years 2010, 2011 and 2014. The number of boys enrolled in KCSE was only high in 2012 and 2013 only as compared to the girls. This is an indication that the boy child education is at stake in the county. This was the basis for the study, to determine the socioeconomic factors that inhibit boy child's participation in education in Baringo County.

Table 1: KCSE Registered Candidates 2010-2014

\begin{tabular}{|l|l|l|l|}
\hline Year & Boys & Girls & Total \\
\hline 2010 & 720 & 800 & 1,520 \\
\hline 2011 & 780 & 811 & 1,591 \\
\hline 2012 & 765 & 730 & 1,495 \\
\hline 2013 & 740 & 733 & 1,473 \\
\hline 2014 & 751 & 760 & 1,511 \\
\hline
\end{tabular}

\subsection{Socio-Economic Factors that Influence Boy-Child Participation and Retention in Secondary Schools}

Poverty has continued to rise in Kenya and it is estimated that $55.4 \%$ live in poverty [18]. Majority of those living in rural areas have limited access to education. The Kenya Integrated Budget Survey of 2005/2006 indicates that the literacy level of those between 15 and 24 years in the ASAL regions is low. Baringo County is no exception. Children from poor households drop out before completion [24] since many families cannot afford rising costs of education [25]. Changach [23] observes that poverty greatly affects transition rates from one level to another. In the same vein, Gathiga [26] notes that students drop out due to poverty, lack of basic needs, insecurity and catastrophes such as drought and famine.

Kenya's erratic economic performance has had adverse effects on provision of education and rising poverty levels. As per the Kenya Integrated Budget and Household Survey [18] (2009/2010), 45.9\% of the population are poor more so those living in the rural areas. Whereas $66 \%$ of boys drop due to rising costs of education, others drop because of truancy (where the child is unwilling to learn because of child labour, drug abuse, and negative attitude to education leading to absenteeism, early marriage as well as HIV and AIDS). Parental level of education and parents' level of income contribute a lot to this. Studies carried in Uganda revealed that the presence of many unproductive members in households leads to poverty and school drop outs result from unemployment of parents, low earnings and poor health. Mc Neal [27] avers that persistent poverty among segments of society leads to drop out of students and this undermines human capital development efforts.

According to Nyanzi [28], the phenomenon of school dropout rate continues to be a challenge to many developing nations. Holmes [29] argues that, overall, those who receive less education tend to drop out especially in rural areas. Kasente [30] and Kakuru [31] explain that early marriage contributes to school dropout among boys. While learners from low socio-economic backgrounds are supported [32] through bursary schemes, huge school fees arrears have driven many boys out of school and some of these boys have either lost their parents to sickness or HIV/AIDS or their parents are hospitalized.

A study carried by Juma [33], in Vihiga, attributed school drop outs to loss of parents, where those orphaned have no one to meet school costs. Olwenya [34], in his study, attributed school drop out to lack of school fees and presence of ready labour market that offers small jobs e.g. hawking while in a survey done in 
Bungoma, it was revealed that boys dropped so as to engage in the popular 'Boda Boda' business, and if action is not taken, boys' education is endangered [20]. A survey carried out by MoE [35] showed that only $23 \%$ of children transited to higher levels of education and revealed that those from poor households are less likely to access or complete secondary education. The gender policy in education formalizes the rights and responsibilities of all people involved directly or indirectly and are expected to eliminate disparities through affirmative action for both boys and girls.

Interventions to curb the dropout rates need to be formulated and implemented. According to a study by UNESCO [16], education is key in reducing poverty, accelerating human development and achieving socioeconomic development. The international communities along with the Kenya Government should address this issue. There should be political commitment to the education of the boy child. Education should be free and compulsory, at the same time equitable and accessible to all. The Government has a great role to play in putting all children to school. Socio-economic imbalances are common particularly among the nomadic communities of Baringo County e.g. Ilchamus and the Pokot yet at independence, commissions were set to address these disparities [36, 37, 38]. There should be impressive and effective measures to keep children in school. There is therefore a need to survey the education system, to check for imbalances. Ogunjuyigbe, Ojofeitimi and Akilo [39] have noted that despite government efforts to promote education, the education system is still faulty. With the introduction of cost sharing, introduced in 1988, parents have to meet some education costs [19]. These costs have adverse effects on students' attendance and retention in public secondary schools especially among those from poor households [40]. Students from poor households drop due to fees arrears [19].

\subsection{Theoretical Grounding}

The study was anchored on the education production function theory. The education production function was found relevant because it suggests that inefficiency in provision of schooling can lead to poor outcomes, hence low participation and retention levels [41, 42].

Education production function theory is based on the general production function that is used to explain the relationship between inputs and outputs of a firm. The study abstract from this function is to investigate how schooling outcomes is a function of a variety of inputs injected into the education process. The origin of estimating input-output relationship in school is usually traced to the acclaimed USA study on equity of opportunity commonly known as the Coleman Report [43]. The report postulated that the education process is the achievement of individual student directly related to series of inputs.

The education output is a function of a series of inputs such as time and quality of the resources. These factors determine the educational outputs such as a measure of internal efficiency in an education system, which may be achieved in assessing student's retention and participation in the education system as a function of socio-economic factors. The study assumed that the outputs of education could be a measure in terms of students who are retained in a school. These students are retained in order to achieve internal efficiency. The study assumed that these factors work interdependently and independently to influence retention and participation of students in a school system. The effect of the socio-economic factors may influence the level of participation and retention of students, differently based on gender. Figure 1 gives a summary of educational inputs and outputs verses their outcomes.

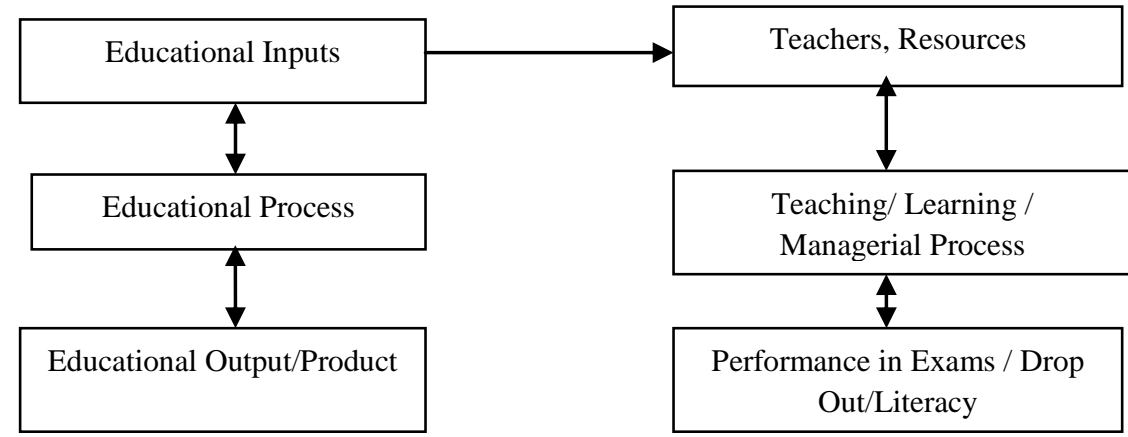

Figure 1: Holistic Operation Model of Efficiency Source: Adapted from Abagi and Odipo [25]

\subsection{Conceptual Framework}

The conceptual framework in Figure 2 shows how the socio-economic factors affect retention and participation in public secondary schools. In the framework, socio-economic factors are the independent variables, whereas the level of participation is the dependent variable. The figure manifests low retention and participation levels in schooling as a product of socio-economic factors that pose challenges to the boy child. It is expected that the boy child facing these challenges is less likely to complete his education. 


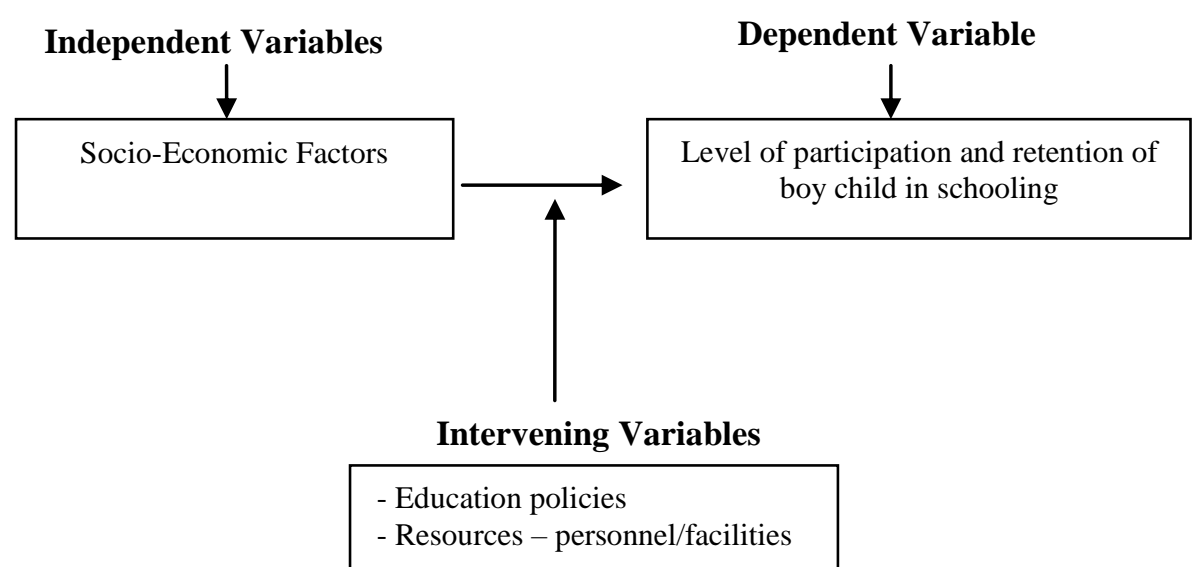

Figure 2: Conceptual Framework

\section{Material And Methods}

The study was carried out in Baringo County, Kenya. This area was chosen for the study because of difficult conditions that seem to affect the school attendance of boys. The methodological design for the study was based on the how and why approach; the logic and underlying philosophy [44, 45, 46]. The study adopted a pragmatic world view hence a mixed method research which calls for a multitude of design, variations, pragmatic combinations and sources, for qualitative and qualitative data. Both inductive and deductive reasoning were used $[47,48]$.

The study targeted form 3 students in public secondary schools in Baringo County and teachers from sampled schools. The target population were teachers, form 3 boy students and Quality Assurance and Standard Officers (QASOs) from Baringo County. Data from the county director of education indicates that there are 70 public secondary schools with a total population of 2780 form three boys and 789 teachers. The researcher used stratified sampling technique to sample different categories of school while simple random sampling was used to select teachers and students who participated in the study. The QASO officers were purposively selected one from each sub-county to participate in the study. The sample size was determined using the coefficient of variation formula [49] as follows:

$$
n=\frac{N C^{2}}{C^{2}+(N-1) e^{2}}
$$

Where $\mathrm{n}=$ Sample Size

$$
\begin{aligned}
& \mathrm{N}=\text { Total Population } \\
& \mathrm{C}=\text { Coefficient of Variation } \\
& \mathrm{e}=\text { Tolerance level }
\end{aligned}
$$

The study applied a coefficient of variation of $11.5 \%$. This is because a coefficient of variation of less than $30 \%$ is considered more appropriate [49] and that coefficient of variation is a more sure measure of variation. Population of 4190 with $1 \%$ tolerance level gave a sample size of 335 respondents as shown below:

$$
\begin{aligned}
n=\quad & 2780 *(0.115)^{2} \\
& (0.115)^{2}+\left((2780-1) *(0.01)^{2}\right. \\
& n=335 \text { students }
\end{aligned}
$$

However, during data cleaning, it was realized that 15 questionnaires were incomplete. This implies that 320 form three boys participated in this study. Form three boys was selected because at that level they have the information required and most of them are 18 years old and will not require consent from parents. Applying the above formula to determine the sample size of teachers from a population of 780 teachers, we get:

$$
\begin{array}{ll}
n=\quad & 780 *(0.115)^{2} \\
& (0.115)^{2}+\left((780-1) *(0.01)^{2}\right. \\
n=256 \text { teachers }
\end{array}
$$

Out of the 256 teachers, 8 did not return their questionnaires. Therefore 248 teachers out of the selected responded items in the questionnaire and students out of the selected 335 students, 320 participated, totalling to 591 respondents who responded to the items in the questionnaire. Data was also collected from 5 QASOs who were purposively selected and interviewed.

The researcher collected data with help of research assistants. The data was collected using questionnaires, interview schedule, observation and document analysis. Qualitative and quantitative data collection techniques were used in the study. Qualitative data were obtained from interviews, while quantitative data were obtained from the structured questionnaire. Data collected was summarized, coded and tabulated, 
using descriptive statistics and inferential statistical techniques. The researcher employed measures of central tendency, measure of dispersion, while multiple regression analysis was used to test the hypothesis.

\subsection{Level of Participation and Retention of Boys}

\section{Results And Discussion}

Majority 127 (39.6\%) of the students felt that the retention and participation levels in their school is high while $92(28.8 \%)$ of them reported that the proportion was low. The remaining $101(31.6 \%)$ indicated that boys' proportion is average. This implies that there was a substantial percentage of boys who do not gain access to secondary school education in Baringo County. This is in agreement with the findings of Mwaniki [8], Kimondo [9] and Gatere [10] who have decried the growing dropout rates among boys in ASAL regions. Table 2 shows the results.

Table 2: Students' Response to Rate of Participation and Retention of Boys

\begin{tabular}{|l|l|l|}
\hline Response & Frequency & Percent \\
\hline Low & 92 & $28.8 \%$ \\
\hline Average & 101 & $31 \% .6$ \\
\hline High & 127 & $39.6 \%$ \\
\hline Total & $\mathbf{3 2 0}$ & $\mathbf{1 0 0 . 0}$ \\
\hline
\end{tabular}

From the results, and as illustrated in Table 3, majority $114(46 \%)$ of the teachers felt that the retention and participation levels in their school is high, while $87(35 \%)$ of them reported that the proportion was average. The remaining $47(19 \%)$ indicated that boys' proportion is low. This implies that there was a substantial percentage of boys who do not gain access to secondary school education in Baringo County. This could be attributed to various factors; among them socio-economic factors.

Table 3: Teacher Response on Retention and Participation Rates

\begin{tabular}{|l|l|l|}
\hline Response & Frequency & Percent \\
\hline Low & 47 & $19 \%$ \\
\hline Average & 87 & $35 \%$ \\
\hline High & 114 & $46 \%$ \\
\hline Total & $\mathbf{2 4 8}$ & $\mathbf{1 0 0 . 0}$ \\
\hline
\end{tabular}

3.2 Socio-Economic Factors Affecting Boys' Retention and Participation in Baringo County - Field Findings

When asked about the socio-economic factors that affects boys' retention and participation in public secondary schools in Baringo County, the teacher respondents gave the responses presented in Table 4 .

Table 4: Teachers' Responses on Socio-Economic Factors Affecting Boys' Retention and Participation

\begin{tabular}{|c|c|c|c|c|c|c|c|c|}
\hline \multirow[t]{2}{*}{ Statement } & \multicolumn{2}{|l|}{$\mathbf{A}$} & \multicolumn{2}{|l|}{$\mathbf{U}$} & \multicolumn{2}{|l|}{ D } & \multicolumn{2}{|c|}{ Total } \\
\hline & $\mathbf{F}$ & $\%$ & $\mathbf{F}$ & $\%$ & $\mathbf{F}$ & $\%$ & $\mathbf{F}$ & $\%$ \\
\hline Poverty & 152 & $61.3 \%$ & 50 & $20.2 \%$ & 43 & $17.3 \%$ & 248 & 100.0 \\
\hline Rising costs of education & 163 & $66 \%$ & 46 & $18.5 \%$ & 39 & $16 \%$ & 248 & 100.0 \\
\hline Desire for quick earnings & 130 & $52.4 \%$ & 11 & $4.4 \%$ & 107 & $43.1 \%$ & 248 & 100.0 \\
\hline Family size/no. of siblings & 117 & $47.1 \%$ & 78 & $31.5 \%$ & 53 & $21.3 \%$ & 248 & 100.0 \\
\hline Family income & 151 & $61 \%$ & 49 & $19.7 \%$ & 48 & $19.3 \%$ & 248 & 100.0 \\
\hline Single parenthood & 108 & $43.5 \%$ & 76 & $30.6 \%$ & 64 & $25.8 \%$ & 248 & 100.0 \\
\hline Child labour & 129 & $52 \%$ & 23 & $9.3 \%$ & 96 & $39 \%$ & 248 & 100.0 \\
\hline Educational attainment of parents & 136 & $55 \%$ & 55 & $22.1 \%$ & 57 & $23 \%$ & 248 & 100.0 \\
\hline
\end{tabular}

It is clear from the table that $152(61.3 \%)$ of the teachers agreed that poverty affects boys" retention and participation while only 43(17.3\%) disagreed, the other 50(20.3\%) were undecided. In addition, rising cost of education was stated as having an impact on boys' retention and participation with $163(66.0 \%)$ of the respondents agreeing, while 39(16\%) objected. The remaining 46(18.5\%) were undecided. It therefore implies that poverty is a major socio-economic setback to boys' retention and participation. The findings also indicate that $130(52.4 \%)$ of the teachers stated that desire for quick earnings affects boys' retention and participation, $11(4.4 \%)$ were undecided while the rest $107(43.1 \%)$ disagreed. Family size/number of siblings determined retention and participation of boy child. $117(47.1 \%)$ agreed to this, while $78(31.5 \%)$ were undecided, the rest $53(21.3 \%)$ objected. Further, 129(52\%) respondents agreed that child labour influenced boy participation in schooling, 23(9.3\%) were undecided, while 96(39\%), disagreed. Low retention and participation level was therefore attributed to child labour. Educational attainment of parents as a factor determining boy schooling was rejected by 57(23\%), $136(55 \%)$ agreed and 55(22.1\%) were undecided. 
This could be attributed to the fact that the poverty levels in Baringo County are high. This directly affects the participation of the boy-child in secondary education since the scarce resources are channelled towards basic survival and education is relegated to a luxury. The findings agree with many other studies that have observed the existence of uneven distribution of educational opportunities between poor and non-poor regions, both in urban and rural areas. These studies have shown that the poor tend to have more limited access to educational opportunities than the non-poor $[16,19,50]$.

The students who participated in this study were also asked to state their opinion concerning the socioeconomic factors that limit boys' retention and participation in school. Table 5 presents their responses.

Table 5: Students' Responses on Socio-Economic Factors Affecting Boys' Retention and Participation

\begin{tabular}{|c|c|c|c|c|c|c|c|c|}
\hline \multirow[t]{2}{*}{ Statement } & \multicolumn{2}{|l|}{$\mathbf{A}$} & \multicolumn{2}{|l|}{$\mathbf{U}$} & \multicolumn{2}{|l|}{ D } & \multicolumn{2}{|c|}{ Total } \\
\hline & $\mathbf{F}$ & $\%$ & $\mathbf{F}$ & $\%$ & $\mathbf{F}$ & $\%$ & $\mathbf{F}$ & $\%$ \\
\hline Parents are poor (poverty) & 237 & $74 \%$ & 22 & $6.9 \%$ & 61 & $19 \%$ & 320 & 100.0 \\
\hline Family size/no. of siblings & 180 & $56.2 \%$ & 46 & $14.3 \%$ & 94 & $29.4 \%$ & 320 & 100.0 \\
\hline Household income & 216 & $68 \%$ & 42 & $13.1 \%$ & 62 & $19.4 \%$ & 320 & 100.0 \\
\hline Single parenthood & 140 & $44 \%$ & 97 & $30.3 \%$ & 83 & $26 \%$ & 320 & 100.0 \\
\hline Child labour /desire for earnings & 178 & $56 \%$ & 83 & $26 \%$ & 59 & $18.4 \%$ & 320 & 100.0 \\
\hline Educational attainment of parents & 162 & $50.6 \%$ & 100 & $31.3 \%$ & 58 & $18.1 \%$ & 320 & 100.0 \\
\hline Rising costs of education & 269 & $84 \%$ & 14 & $4.4 \%$ & 37 & $11.6 \%$ & 320 & 100.0 \\
\hline
\end{tabular}

As shown in Table 5, 237(74\%) of the respondents agreed that the poverty of parents' limits boys' retention and participation while 61(19\%) disagreed that this role was played by poverty. The remaining $22(6.9 \%)$ were undecided. As stated by UNESCO [16], the problems are worst in countries with high poverty, exclusion, and poor-quality schools. In general, children are more likely to be out of school if they come from poor households, live in rural areas and have mothers who received no education. At the same time, it was revealed that $180(56.2 \%)$ of the respondents agreed that the size of family, hence many siblings limit boys' participation and retention from primary to secondary while 94(29.4\%) disagreed. The remaining $46(14.3 \%)$ were not decided. When asked whether single parenthood affects boy schooling, 140(44\%) agreed, 83(26\%) objected, while 97(30.3\%) were undecided. Child labour and desire to earn is believed to affect boy schooling. $178(56 \%)$ agreed on this, $83(26 \%)$ were undecided, while 59(18.4\%) did not agree. Education attainment of parents is key in boy child retention and participation. 162(50.6\%) agreed, 58(18.1\%) disagreed, while $100(31.3 \%)$ were undecided. Finally, when the respondents were asked whether the rising costs of education influences boy retention and participation in schooling, a majority, 269(84\%) agreed, 37(11.6\%) disagreed and the remaining $14(4.4 \%)$ were undecided.

From these findings, it can be concluded therefore that the rising costs of education and poverty were the main factors to low retention and participation of boy child in schooling. However, family size or the number of siblings was least among the factors.

The QASO interviewed agreed that socio-economic challenges greatly determined level of retention and participation of boy child in the county. They mentioned poverty and rising costs of education as a great obstacles and a hindrance to boy-child schooling. This implies that poverty, to some extent, limits boys' participation and retention in secondary in Baringo County. However, from the interviews it was realized that the inheritance of property from parents made the students feel economically contented.

\subsection{Regression Analysis and Hypothesis Testing}

A multiple regression equation was used to evaluate the relationship between the independent variables used in this study and the dependent variable. Using SPSS (version 20), a multiple regression analysis involving the constructs of socio-economic factors was used to determine the actual prediction equation and show the direction, avoid multicollinearity and strength of the relationship among the variables. All the items were measured in a five-point Likert scale.

To undertake multiple regression analysis, the responses in each variable were transformed into composite means using SPSS version 20 before generating the regression output. The components of the multiple linear regression analysis used in this study are the Model Summary, the ANOVA Summary and the Table of Coefficients. Table 6 presents the results.

Table 6: Coefficients Used in the Multiple Regression Equation

\begin{tabular}{|l|l|l|l|l|}
\hline Variable & Beta Value & t-statistics & p-value & Remarks \\
\hline Socio-Economic Factors & 0.082 & 1.214 & 0.018 & Significant \\
\hline Constant & 1.826 & & \\
\hline
\end{tabular}


As shown in Table $6, \mathrm{R}^{2}$ was $0.742 . \mathrm{R}^{2}$ is the coefficient of determination which shows the proportion of the variance in the dependent variable that can be explained by variation in the independent variables. Therefore $74.2 \%$ in the variation in level of participation and retention of boy-child can be explained by differences in the independent variable (socio-economic factors). The remaining $25.8 \%$ variation in the level of participation and retention of boy-child can be explained by other variables not covered in the study. The table also shows an F-ratio of 22.183 with degrees of freedom of 6 and 104, $<<0.05$. In other words, the dependent variable can be predicted from the independent variable. This implies that there was a significant regression equation at 0.05 level of significance.

To examine the relationship between socio-economic factors and level of participation and retention of boy-child in secondary schooling, a null hypothesis that stated that "there is no statistically significant relationship between socio-economic factors and participation and retention of boy child in secondary schooling" was formulated. After running regression analysis, the results indicated a significant and positive relationship between socio-economic factors and participation and retention of boy child in secondary schooling as shown in Table 6 ( $\mathrm{p}$-value $=0.018 ; \beta=0.082$ ). Consequently, the null hypothesis was rejected and the alternative accepted.

\section{Conclusions And Recommendation}

This paper has demonstrated that the retention and participation level of the boy-child in public secondary schools in Baringo County is low. As such, there is a substantial percentage of boys who do not gain access to secondary school education in Baringo County. In addition, it has been established that poverty is a major factor that affects the participation and retention of boys in public secondary schools in Baringo County. Furthermore, family size and number of siblings per household have an impact on boys' participation and retention. The paper has also shown that child labour and desire for earnings are other factors key in determining boy schooling in public secondary schools in Baringo County. Lastly, educational attainment of parents determines boy participation and retention in public secondary schools in Baringo County. It is, therefore, the conclusion of this paper that financial constraints hinder the participation and retention of boys in public secondary schools in Baringo County due to the fact that the meagre resources that are available are channelled to catering for basic survival. The paper recommends that measures should be put in place to ensure that needy students receive financial aid towards achieving their educational goals.

\section{References}

[1] World Bank, (2005). Expanding opportunities and Building Competence for Young People: A New Agenda for Secondary School Education. Washington, DC: The International Bank for Reconstruction.

[2] UNESCO (2001). Education For All-Status and Trends Wasted: Opportunity. Paris: UNESCO.

[3] Alvarez, B., Gillies, J., \& Bradsher, M. (2003). Beyond Basic Education: Secondary Education in the Developing World. Washington, D.C. The International Bank for Reconstruction and Development /The World Bank.

[4] Lazear, E. (Ed.) (2002). Education in the Twenty First Century. New York: Hoover Institution Press.

[5] UNESCO (2005). EFA Global Monitoring Report 2005. New York: UNESCO.

[6] Oanda, I., \& Akudolu, L. (2010). Higher Education in Africa: Equity, Access Opportunity. New York: Institute of International Education (IIE).

[7] Todaro, P. M. (1994). Economic Development ( $5^{\text {th }}$ Ed). New York: Longman Publishers.

[8] Mwaniki, M. (2008, May 7). Pregnancies kick girls out of school .The Daily Nation. p. 5.

[9] Kimondo, C. (2007). Girls Beat Boys in Attendance. Teachers Image Quarterly magazine by TSC

[10] Gatere, A. (2007). No Schooling Please, we are Igembe Boys. Teachers' Image, A Quarterly Magazine by the TSC, 14, 34-35.

[11] Njeru, E. H., \& Orodho, J. A. (2003) Access and Participation in Secondary School Education in Kenya. Nairobi: IPAR.

[12] Awiti J. A. (2004). A Study on Major Factors Contributing to Secondary School Dropout in Kisumu District. Unpublished Master of Education Thesis, University of Nairobi, Nairobi.

[13] Akyeampong, K. (2009) Revisiting Free Compulsory Universal Basic Education (FCUBE) in Ghana. Comparative Education, 45(2), 175-195.

[14] Rolleston, C. (2009). The Determination of Exclusion: Evidence from Ghana Living Standard Surveys 1991-2006. Comparative Education, 45(2), 197-218.

[15] Chimombo, J. (2009). Changing Patterns of Access to Basic Education in Malawi. Comparative Education, $297-312$.

[16] UNESCO. (2007). Global Education Digest. New York: UNESCO

[17] Admassie, A. (2002). Explaining the High Incidence of Child Labour in Sub-Saharan Africa. African Development Review, 14(2), 251-275.

[18] Republic of Kenya. (2007). Gender Policy in Education. Nairobi: Ministry of Education.

[19] Wanjiru, W. J. (2012). The impact of Policy on Cost Sharing: A Case Study of Selected Kenyan Secondary Schools. Retrieved from http://www.uir.unisa.za/handle/10500/6311

[20] Hamasi, L. (2013). The Boy Child and New Gender Imperatives in Kenya: Investigating School Dropout among boys in Marakwet County. Kenya Studies Review, 6(2), 51-67.

[21] Nyongesa, B. (2007). Educational Management. Nairobi: Jomo Kenyatta Foundation.

[22] [22]Okello, E. (2012). African Boy, an Endangered Species. Retrieved from http:/www/African executive com/modules/magazine/articles.php?articles.

[23] Changach, J. K. (2012). Education for Development: Myth or Reality? The Kenyan Experience. International Journal of Learning and Development, 2(3), 144-159. 
[24] Dobson, J., Henthorne, K. \& Lynas, Z. (2000). Pupil Mobility in Schools: Final Report. Migration Research Unit, University College.

[25] Abagi, O. \& Odipo, G. (1997). Efficiency of Primary Education in Kenya: Situation and Implication for Education Reform. Discussion Paper, No. DP004/97.

[26] Gathiga, M. (2010). Student Drop out on Increase. Retrieved from www.globalissues.org/news/20110/12/8062

[27] Mc Neal, R. B. (1995). Extracurricular Activities and High School Dropouts. Sociology of Education, 68(1), 62-81.

[28] Nyanzi, L. (2002). Gendering Education Policy: The Uganda Case. Women's Worlds Conference Paper.

[29] Holmes, J. (2003). Measuring the Determinants of School Completion in Pakistan: Analysis of Censoring and Selection Bias. Economics of Education Review 22.

[30] Kasente, D. (2004). Gender and Education in Uganda: A Case Study for Monitoring Report. Unpublished Thesis, Makerere University, Kampala.

[31] Kakuru D. M. (2003). Gender Sensitive Educational Policy and Practice: Uganda Case Study. Kampapla: UNDP Uganda Country Office.

[32] MoE (2005). Report on Increased Enrolment due to FPE and SSE. Retrieved October, 112015 from World bank.Org/INT KENYA/resources/gov-education -sector.

[33] Juma (2003). The Nature, Trend, and Factors Causing Wastage in Secondary School Education in Vihiga District, Kenya. Unpublished Master of Education Thesis, Maseno University, Kisumu.

[34] Olwenya, J. A. (1996). Educational Wastage among Girls in Kenyan Secondary Schools: A Case Study of Homa Bay District. Unpublished Master of Philosophy Thesis, Moi University, Eldoret.

[35] MoE (2012). Report on the Policy Framework for Nomadic Education in Kenya. Nairobi: Government Printer.

[36] Republic of Kenya. (1964). Report of the Kenya Education Commission. Nairobi: English Press Limited.

[37] Republic of Kenya. (1976). Report on the National Committee on Educational Objectives and Policies. Nairobi: Government Printer.

[38] Republic of Kenya. (1997). Economic Survey, National Development Plan 1997-2001. Nairobi: Government Printer.

[39] Ogunjuyigbe, P. O., Ojofeitimi, E. O., \& Akilo, A. (2006). Science Education in Nigeria: An Examination of People's Perceptions about Female Participation in Science, Mathematics and Technology. Journal of Science Education and Technology, 16, (1), 277284

[40] Wasunna, O., \& Abagi, O. (2000). Cost Sharing in Education and Health in Kenya. Nairobi: Institute of Policy Analysis and Research.

[41] Patrinos, H., \& Psacharopoulos, G. (2004). Family Size, Schooling, and Child Labor in Peru - An Empirical Analysis. J. Popul. Econ., 10, 387-405.

[42] Hanushek, E. A., \& Kimko, D. D. (2000). Schooling, Labour Force Quality, and the Growth of Nations. American Economic Review, 90(5), 1184-1208.

[43] Coleman, J. S. (1996). Equality of Educational Opportunities. Washington DC: US Government Printing Office

[44] Kothari, C. R. (2004). Research Methodology: Methods and Techniques. New Delhi: New Age International Publishers, India.

[45] Bryman, A. (2004). Social Research Methods $\left(2^{\text {nd }}\right.$ Ed). Oxford: OUP.

[46] Creswell, J. W. (2012). Educational Research: Planning, Conducting, and Evaluating Quantitative and Qualitative Research (5 Ed). New Jersey: Pearson.

[47] Tashakhkori, A., \& Teddlie, C. (2003). Handbook of Mixed Methods in Social and Behavioural Research. Thousand Oaks: Sage

[48] Mertens, D. (2005). Research and Evaluation in Education and Psychology: Integrating Diversity with Qualitative, Quantitative and Mixed Methods $\left(2^{\text {nd }}\right.$ Ed). California: Sage Publications.

[49] Nassiuma D. K. (2000). Survey Sampling: Theory and Methods. Njoro: Egerton University Press.

[50] Myers, R. (1997). Removing Roadblocks to Success: Transition to Secondary School. Journal of Educational and Statistics, 29, 241-244. 